\title{
LYNX SPIDERS OF KHULNA DISTRICT OF BANGLADESH : GENUS OXYOPES LATREILLE (AREANEAE : OXYOPIDAE)
}

\author{
V. Biswas ${ }^{*}$ and D. Raychaudhuri ${ }^{1}$ \\ Department of Zoology, Khulna Government Women's College, Khulna-9000, Bangladesh.
}

\begin{abstract}
A study on the lynx-spiders was carried out from different areas of Khulna district of Bangladesh. Six (6) species of the genus Oxyopes Latreille were identified of which four (4) species were recorded for the first time from Bangladesh. The paper contains a description and distribution together with key to the species.
\end{abstract}

Key words : Lynx-spider, Araneae, Oxypidae, Bangladesh.

\section{INTRODUCTION}

The Lynx spider genus Oxyopes Latreille have received serious attention since Pocock (1901) as one of the important members in the gardens and crop-fields. The genus was established by Latreille in 1804 with type-species Oxyopes heterophthalmus and is represented by 297 species worldwide (Platnick 2015). In Bangladesh, a little records are found on these spiders (Chowdhury and Nagri 1981, Chowdhury and Pal 1984, Kamal et al. 1992, Biswas et al. 1993, Okuma et al. 1993).

Many workers reported on this genus from Indian Sub-continent and other Asian countries (Tikader 1970, Biswas et al. 1996, Saha and Raychaudhuri 2003, '04, Mukhtar and Mustaq 2005, Song et al. 1999, Yin et al. 2003). In India are : Sherriffs (1951), Tikader (1965, '69, '70), Patel (1978), Tikader and Biswas (1981), Gajbe (1992, '99, 2008), Biswas et al. (1996), Sadana and Gupta (1995), Saha and Raychaudhuri (2003, '04, '07), Sen et al. (2011), Bodkhe and Venkhede (2012) ; in Pakistan are : Mukhtar (2013a, b), Mukhtar and Mustaq (2005), Mustaq and Qadar (1999) ; in China are : Zhao (1993), Xie and Kim (1996), Song et al. (1999), Hu (2001), Yin et al. (2003), Zhang and Zhu (2005), Tang and Li (2012) ; in the Philippines : Barrion and Litsinger (1995) ; in Korea are : Kim and Cho (2002), Namkung $(2002,2003)$; in Japan are : Yaginuma (1986), Ono and Ban (2009) and in Singapore Koh (1989).

Present study contains a description of six species of the genus Oxyopes from Khulna, Bangladesh.

* Corresponding author: vivekarach@gmail.com. 1Entomology Laboratory, Department of Zoology, Calcutta University, 35, B. C. Road, Kolkata-700019, India.

(C) 2015 Zoological Society of Bangladesh DOI: 10.3329/bjz.v43i2.27394 


\section{MATERIAL AND METHODS}

Study area : The study was made with the collection of spiders from different crop-fields and gardens of Khulna district (vide Map-1). District Khulna is located on the southwestern part of Bangladesh, has an area of 4394.45 squre kilometers . It is bordered on the north by Jessore and Narail district, on the east by Bagerhat district, on the west by Satkhira district and on the south by the Bay of Bengal. Khulna district is known to have a vast coastal area with regular experience of oceanic tides. On the southern aspect of the district, just adjacent to the Bay of Bengal, there is the mangrove forest "Sunderban" exists.

Naturally, the whole Khulna district is evergreen and composed of numerous kinds of green plants. The district has 10 (ten) upazilas namely- Khulna Sadar, Batiaghata, Dacop, Digholia, Dumuria, Phultala, Koira, Paikgacha, Terokhada and Rupsa. The specimens were collected from each of the upazilas and the locations are indicated in the Map- 1.

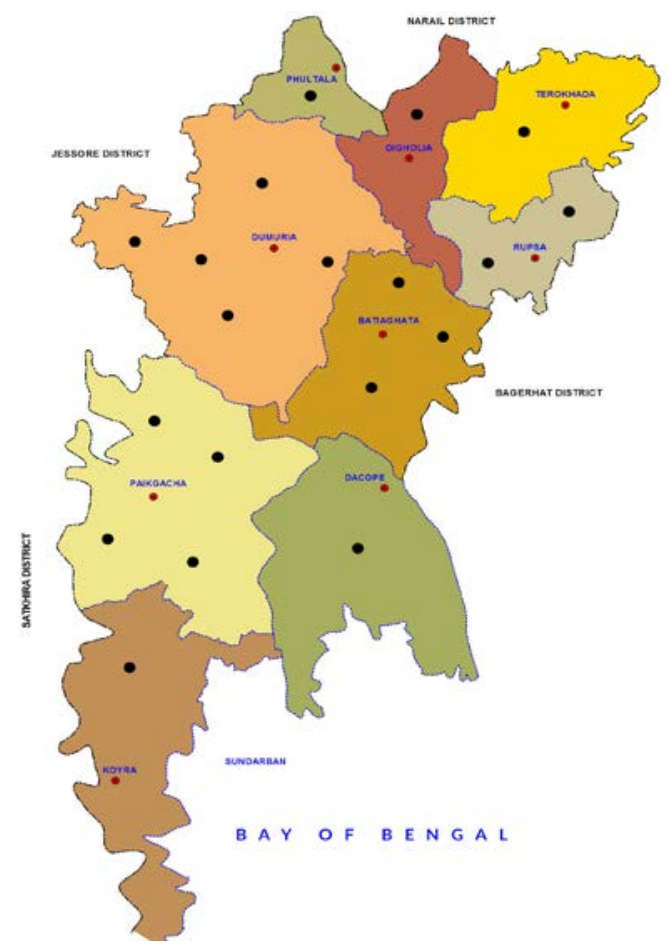

Fig. 1. Showing different collected localities/areas (Upazilas) of Khulna district.

Collection : Lynx spiders cannot spin any web but are very claver and can jump a little distance from one plant to another. They have spiny body and difficult to catch them by hand. Therefore, during collection, different techniques were applied following their behavior and position on the plant leaves. 
The spiders were collected by sweep nets (different sizes) from the fields. The collections were also made from the trees by shaking the branches and were collected on an inverted umbrella placed underneath the trees (Tikader 1987).

The collected specimens were anesthesized with chloroform in a killing jar and they were then transferred to a petridish filled with $70 \%$ ethyl alcohol for sorting.

Preservation : After sorting, the spiders were brought to the laboratory. The specimens were thus kept for 2-3 hours for relaxation of body muscles as suggested by Chowdhury and Nagari (1981). The body parts of the spiders (e.g. legs, pedipalps etc.) were stretched by using fine brushes, forceps, needles etc. This was done in alcohol-filled petridishes. The specimens were then preserved in the specimen-vials (single specimen was placed in a single vial). For permanent preservation, Audman's preservative (as solution of 85 parts $70 \%$ alcohol, 5 parts glycerine and 5 parts glacial acetic acid) was used following Lincola and Sheals (1979) and Tikader (1987) and it was changed after 1-2 days as it might be diluted with body fluids.

The preserved types are at present in the collection of the Department of Zoology, Khulna Govt. Womens' College, Khulna and will be deposited to the Museum of the Department of Zoology, University of Dhaka, Bangladesh.

Identification : The spiders were then identified following Pocock (1900, 1901), Brady (1964), Tikader (1965, '66, '70 and '87), Patel (1978), Dondale and Redner (1995), Yaginuma (1986), Okuma et al. (1993), Song et al. (1999) and Gajbe (2008). The identities of the specimens were later confirmed from the Zoological Survey of India, Kolkata.

Method of Study : The spiders were arranged in a petridish or cavity block on submerged cotton or white beach sand filled with alcohol for studies under a binocular microscope. During the study, the female epigynum and male pedipalps were dissected out systematically. After dissection, the epigynum was cleared in clove oil for 6-12 hours (Tikader 1987). The epigynum was kept permanently in a micro-vial corked with tissue paper along with the mother spider in a larger tube and preserved in rectified spirit or $80 \%$ alcohol or Audman's preservative.

The male pedipalps, after removal from the body, were boiled first in $10 \% \mathrm{KOH}$ solution for 5-10 minutes. Thus, the different parts were expanded and placed under the binocular microscope for study. The male palps were also kept in the same way along with the male specimen in $70 \%$ alcohol or Auman's preservative permanently.

The figures were drawn with the help of a Camera Lucida fitted with the Stereo-binocular microscope (SV8, Zeiss). The photographs were taken from the field in different natural conditions and some photographs were also taken (for small specimens) with the Camera fitted with Stereo binocular microscope. 


\section{RESULTS AND OBSERVATION}

Genus Oxyopes Latreille, 1804.

1804. Oxyopes Latreille, Nauv. Dict.Hist. Nat., 24 : 135.

Diagnosis : Cephalothorax longer than wide and attenuated anteriorly. Eyes subequal ; anterior eyes arranged in trapezium, posterior row of eyes strongly procurved and situated equidistantly from others. Ocular quadrangle longer than wide and limited by the posterior median eyes and the anterior lateral eyes. Clypeus not narrowed than the ocular area. Cheliceral margins atmost with few teeth. Legs long and slender, with strong, pointed spines.

Type-species: Oxyopes heteropthalmus Latreille.

Distribution : ASIA ; AFRICA ; AMERICA and EUROPE.

\section{Key to the species}

1. Cephalothorax elongately oval, anteriorly narrowed 2

- Cephalothorax broadly oval, anteriorly broad

2. Eyes enclosed in black field; each of cheliceral margins with 2 teeth

sikkimensis

- Eyes never enclosed in a black field ; cheliceral margins never with such combination of teeth 3

3. Outer margin of chelicerae with 2 teeth ; labium pear-shaped ; epigyne and male palp typical javanus

- Outer margin of chelicerae without any teeth ; labium pot-like epigyne and male palps typical and not as above

4. Abdomen with a mid-longitudinal black band extending upto middle ; cervical furrows distinct ; sternum anterioly broad posteriorly narrowed and pointed

sitae

- Abdomen with a mid-longitudinal band extending upto the tip ; cervical furrows absent ; sternum globose sunandae

5. Abdomen posteriorly broad ; cervical furrows deeply impressed ; maxillae cylindrical ; sternum heart-shaped

ratnae

- Abdomen posteriorly pointed ; cervical furrows not impressed ; maxillae foot-like ; sternum elongate pandae 


\section{Oxyopes javanus Thorell}

(Figure 2, a - g)

1877. Oxyopes javanus Thorell, Ann. Mus. Civ. St. Nat., Genova, 25 : 329.

2015. Oxyopes javanus : Platnick, World Spider Catalog. Version 15.0, http//research.amnh.org/iz/spiders/catalog/int ro.html

Material examined : $2+$, Jhenidah, 18.II.1995, Coll. V. Biswas ; 10, Dumuria, 12.X.1994, Coll. V. Biswas ; 1우, Chitalmari, 05.IX.1993, Coll. V. Biswas ; 10, 2 우, Fakirhat, 09.X.1994, Coll. V. Biswas.

General : Cephalothorax and legs greenish-yellow. Total body length (female) $9.21 \mathrm{~mm}$. Carapace $3.00 \mathrm{~mm}$ long, $2.90 \mathrm{~mm}$ wide ; abdomen $6.21 \mathrm{~mm}$ long and $3.00 \mathrm{~mm}$ wide. Total length (male) $7.30 \mathrm{~mm}$. Carapace $2.90 \mathrm{~mm}$ long, $2.80 \mathrm{~mm}$ wide ; abdomen $4.40 \mathrm{~mm}$ long and $2.95 \mathrm{~mm}$ wide.

Cephalothorax : Greenish-yellow, broad, longer than wide, anteriorly narrowing, cephalic region slightly raised without any fovea, lateral striae present. Eyes hexagonal, acular area laterally expanded (Fig. 2a). Anterior row of eyes recurved and posterior row procurved. Chelicerae brown, outer margin with 2 teeth (Fig. 2b). Maxillae brownish, longer thane wide, anteriorly scopulate (Fig. 2c). Labium brownish, pear-shaped, scopulate anteriorly (Fig. 2c). Sternum longer than wide nearly heart-shaped, pointed posteriorly (Fig. 2d). Legs long with strong, black spines ; leg formula and the measurement (in mm) 1423.

Table 1. Measurement (mm) of leg segments of Oxyopes javanus Thorell

\begin{tabular}{ccccccc}
\hline Leg & Femur & Patella & Tibia & Metatarsus & Tarsus & Total \\
\hline I & $5.00 / 5.00$ & $2.05 / 2.05$ & $3.00 / 3.00$ & $3.50 / 3.50$ & $2.00 / 2.00$ & $15.55 / 15.55$ \\
II & $3.50 / 3.50$ & $1.15 / 1.15$ & $3.00 / 3.00$ & $3.00 / 3.00$ & $1.00 / 1.00$ & $11.65 / 11.65$ \\
III & $2.50 / 2.50$ & $1.00 / 1.00$ & $2.05 / 2.05$ & $2.00 / 2.00$ & $0.85 / 0.85$ & $8.40 / 8.40$ \\
IV & $4.55 / 4.55$ & $1.50 / 1.50$ & $3.05 / 3.05$ & $2.50 / 2.50$ & $1.50 / 1.50$ & $12.60 / 12.60$ \\
\hline
\end{tabular}

Male palp as in Fig. 2f-g.

Abdomen : Greenish-yellow ; broadly elongate, nearly cylindrical, posteriorly pointed with pointed spinnerets ; dorsum covered with curved striae and a pair of sigilla ; ventrally pale-yellow, epigyne as if Fig. 2e.

Distribution : BANGLADESH : Bagerhat, Barsal, Gazipur, Jessore, Kustia, Mymensingh, Fridpur, Khulna ; The PHILIPPINES ; THAILAND ; JAPAN (Okuma 1968, Barrion and Litsinger 1995). 


\section{Oxyopes pandae Tikader}

(Figure 3, a - e)

1969. Oxyopes pandae Tikader, Oriental Insects, 3(1) : 33.

2015. Oxyopes pandae : Platnick, World Spider Catalog. Version 15.0, http://research.amnh.org/iz/spiders/catalog/intro.html

Material examined : $1 \hat{\jmath}$, Bagerhat, 12.V.1992, Coll. V. Biswas; $1 \hat{\jmath}$, Fultala, 9.IX.1993, Coll. V. Biswas ; 1으, Bagerhat, 18.X.1995, Coll. V. Biswas.

General : Cephalothroax and legs yellowish green; abdomen yellowish. Total body length (male) $10.20 \mathrm{~mm}$. Carapace $4.50 \mathrm{~mm}$ long, $3.30 \mathrm{~mm}$ wide ; abdomen $5.70 \mathrm{~mm}$ long and $2.00 \mathrm{~mm}$ wide.

Cephalothroax : broad, longer than wide, posteriorly wide and anteriorly narrowed; cephalic region little raise, with a Y-shaped brown marking; thoracic region centrally with a brown marking. Eyes similar, each basally ringed with black band. Anterior row recurved and posterior row procurved; ocular quad wider than long, posteriorly wide and anteriorly narrowed. Chelicerae brown, only inner margin with 1 tooth (Fig. 3b). Maxillae brownish, longer than wide, anteriorly broad and scopulate (Fig. 3c). Labium basally broad and anteriorly narrowed and scopulate (Fig. 3c). Sternum longer than wide, cylindrical, posteriorly narrowed and pointed (Fig. 3d). Legs long, with black strong spines and fine hairs; leg formula and the measurements (in $\mathrm{mm}$ ) : 1423.

Table 2. Measurements ( $\mathrm{mm}$ ) of leg segments of Oxyopes pandae Tikader

\begin{tabular}{ccccccc}
\hline Leg & Femur & Patella & Tibia & Metatarsus & Tarsus & Total \\
\hline I & $5.00 / 5.00$ & $2.00 / 2.00$ & $3.00 / 3.00$ & $3.50 / 3.50$ & $2.00 / 2.00$ & $15.50 / 15.50$ \\
II & $3.50 / 3.50$ & $1.10 / 1.10$ & $3.00 / 3.00$ & $3.00 / 3.00$ & $1.00 / 1.00$ & $11.60 / 11.60$ \\
III & $2.50 / 2.50$ & $1.00 / 1.00$ & $2.00 / 2.00$ & $2.00 / 2.00$ & $0.80 / 0.80$ & $8.30 / 8.30$ \\
IV & $4.50 / 4.50$ & $1.50 / 1.50$ & $3.00 / 3.00$ & $2.50 / 2.50$ & $1.50 / 1.50$ & $12.50 / 12.50$ \\
\hline
\end{tabular}

Male palp as in Fig. 3e.

Abdomen : long, cylindrical, medially wide, posteriorly narrowed; dorsum with some lingitudinal black markings; spinnerets long, ventrally pale yellow, with a median black-line.

Distribution : BANGLADESH; Barisal, Faridpur and Bagerhat; INDIA (Tikader 1969, Gajbe 1999). 


\section{Oxyopes ratnae Tikader}

(Figure 4, a - f)

1970. Oxyopes ratnae Tikader, Rec. zool. Surv. India, 64 : 70.

2015. Oxyopes ratnae: Platnick, World Spider Catalog. Version 15.0, http:// research.amnh.org/iz/spiders/catalog/intro.html

Material examined : 2ㅇ, Jhenidah, 12.VI.1991, Coll. V. Biswas; 1, 1 $\widehat{\jmath}$, Rajshahi, 3.III.1992, Coll. V. Biswas; 1우 Tangail, 28.IX.1992, Coll. V. Biswas; 1 , Thakurgaon, 4.IX.1990, Coll. V. Biswas.

General : Cephalothroax and legs greenish brown; abdomen dirty white with some black markings. Total body length (female) $10.20 \mathrm{~mm}$. Carapace $3.50 \mathrm{~mm}$ long, $3.00 \mathrm{~mm}$ wide ; abdomen $6.70 \mathrm{~mm}$ long and $4.10 \mathrm{~mm}$ wide. Total body length (male) $6.10 \mathrm{~mm}$. Carapace $1.90 \mathrm{~mm}$ long, $1.00 \mathrm{~mm}$ wide ; abdomen 4.20 $\mathrm{mm}$ long and $2.00 \mathrm{~mm}$ wide.

Cephalothroax : longer than wide, posteriorly broad, anteriorly narrowing; medially with a brown, longitudinal fovea; cephalic region raised, with cervical furrows deep and distinct; radii present. Eyes brownish, prominent, larger, ringed recurve and posterior row procurved. Chelicerae brown, strong, longer than wide, only inner margin with 1 tooth (Fig. 4b). Maxillae brown, long, aneriorly wide and scopulate (Fig. 4c). Labium brown, medially constricted, anteriorly wide and scopulate (Fig. 4c). Sternum brown, heart-shaped, posteriorly produced and pointed (Fig. 4d). Legs long and slender, clothed with black, strong spines; leg formula and the measurements (in $\mathrm{mm}$ ) : 4132 .

Table 3. Measurements ( $\mathrm{mm}$ ) of leg segments of Oxyopes ratnae Tikader

\begin{tabular}{ccccccc}
\hline Leg & Femur & Patella & Tibia & Metatarsus & Tarsus & Total \\
\hline I & $4.00 / 4.00$ & $1.30 / 1.30$ & $3.00 / 3.00$ & $2.00 / 2.00$ & $1.00 / 1.00$ & $11.30 / 11.30$ \\
II & $2.00 / 2.00$ & $0.90 / 0.90$ & $1.80 / 1.80$ & $1.60 / 1.60$ & $0.80 / 0.80$ & $6.30 / 6.30$ \\
III & $3.50 / 3.50$ & $1.00 / 1.00$ & $2.00 / 2.00$ & $1.80 / 1.80$ & $0.90 / 0.90$ & $9.20 / 9.20$ \\
IV & $4.50 / 4.50$ & $1.50 / 1.50$ & $3.50 / 3.50$ & $2.00 / 2.00$ & $1.50 / 1.50$ & $13.00 / 13.00$ \\
\hline
\end{tabular}

Male palp as in fig. $4 \mathrm{f}$.

Abdomen : long, cylindrical, longer than wide, anteriorly broad and posteriorly narrowed, clothed with fine hairs and pubescence; dorsum medially with a white longitudinal band; median spinneret broad, laterals thin; ventrally pale green, with a median longitudinal blackish line extending from epigastric furrow to the spinnerets; epigyne as in fig. 3e.

Distribution : BANGLADESH; Jhenidah, Rajshahi, Tangali, Thakurgaon; INDIA (Tikader 1970, Tikader and Biswas 1981). 


\section{Oxyopes sikkimensis Tikader}

(Figure 5, a - f)

1970. Oxyopes sikkimensis Tikader, Rec. zool. Surv. India, 64(1-4) : 76.

2015. Oxyopes sikkimensis : Platnick, World Spider Catalog. Version 15.0, http://research.amnh.org/iz/spiders/catalog/intro.html

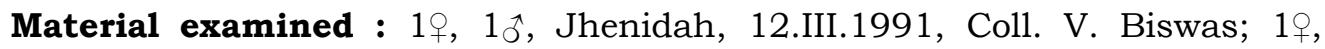
Khulna, 18.VIII.1992, Coll. V. Biswas; 1웃ㅅㅅ Kustia, 25.X.1992, Coll. V. Biswas; 1으, Rajshahi, 3.III.1992, Coll. V. Biswas; 1우 Rangpur, 21.III.1992, Coll. V. Biswas.

General : Cephalothroax and legs brown green; abdomen brownish. Total body length (female) $14.20 \mathrm{~mm}$. Carapace $6.20 \mathrm{~mm}$ long, $4.80 \mathrm{~mm}$ wide ; abdomen $8.00 \mathrm{~mm}$ long and $2.10 \mathrm{~mm}$ wide. Total body length (male) $10.50 \mathrm{~mm}$. Carapace $4.00 \mathrm{~mm}$ long, $2.50 \mathrm{~mm}$ wide ; abdomen $6.50 \mathrm{~mm}$ long and $1.50 \mathrm{~mm}$ wide.

Cephalothroax : elongately oval, longer than wide, posteromedially wide, anteriorly narrowed; thoracic region with median, longitudinal brown fovea, laterally with linearly arranged short spines. Eyes brownish, similar, enclosed in a black field, anterior row recurved and posterior row procurved; anteriorly with 2 small ocelli. Chelicerae brown, clothed with spines and hairs, each of inner and outer margins with 2 teeth (fig. $5 \mathrm{~b}$ ). Maxillae long, medially narrow, anteriorly wide and scopulate (fig. 5c). Labium brown, anteriorly scopulate (fig. 5c). Sternum brown, longer than wide, medially wide, posteriorly narrowed and pointed (fig. 5d). Legs long and slender, clothed with strong, black spines; leg formula and the measurements (in $\mathrm{mm}$ ) : 1243.

Table 4. Measurements $(\mathrm{mm})$ of leg segments of Oxyopes sikkimensis Tikader

\begin{tabular}{ccccccc}
\hline Leg & Femur & Patella & Tibia & Metatarsus & Tarsus & Total \\
\hline I & $4.50 / 4.50$ & $1.00 / 1.00$ & $3.50 / 3.50$ & $3.00 / 3.00$ & $1.50 / 1.50$ & $13.50 / 13.50$ \\
II & $4.00 / 4.50$ & $1.00 / 1.00$ & $3.00 / 3.00$ & $3.00 / 3.00$ & $1.00 / 1.00$ & $12.00 / 12.00$ \\
III & $3.00 / 3.00$ & $0.90 / 0.90$ & $2.00 / 2.00$ & $2.00 / 2.00$ & $0.90 / 0.90$ & $8.80 / 8.80$ \\
IV & $4.00 / 4.00$ & $1.00 / 1.00$ & $2.90 / 2.90$ & $2.80 / 2.80$ & $1.00 / 1.00$ & $11.70 / 11.70$ \\
\hline
\end{tabular}

Male palp as in fig. $5 f$.

Abdomen : elongate, anteriorly wide and posteriorly narrowed; dorsum with few black markings and a medial ' $U$ '-shaped brown band; epigyne as in fig. 5e.

Distribution : BANGLADESH ; Jhenidah, Khulna, Kustia, Rajshahi, Ranpur ; INDIA (Tikader 1970, Biswas and Biswas 1992). 


\section{Oxyopes sitae Tikader}

(Figure 6, a - e)

1970. Oxyopes sitae Tikader, Rec. zool. Surv. India, 64(1-4) : 75.

2015. Oxyopes sitae : Platnick, World Spider Catalog. Version 15.0, http://research.amnh.org/iz/spiders/catalog/intro.html

Material examined : 1으, ADI, Faridpur, 12.V.1992, Coll. V. Biswas; 1웅 Jhenidah, 19.VII.1992, Coll. V. Biswas; 1언 Khulna, 9.X.1993, Coll. V. Biswas.

General : Cephalothroax and leg greenish brown; abdomen pale brown with black lines. Total body length (female) $11.50 \mathrm{~mm}$. Carapace $5.30 \mathrm{~mm}$ long, 4.00 $\mathrm{mm}$ wide ; abdomen $6.20 \mathrm{~mm}$ long and $2.00 \mathrm{~mm}$ wide.

Cephalothroax : longer than wide, posteriorly broad; cephalic region raised with distinct cervical furrows; thoracic region with median longitudinal dark brown fovea. Eyes prominent, similar, each ringed with black basal band; anterior row recurved while posterior row procurved; anteriorly with 2 small ocelli. Chelicerae brown, long, strong, each of inner and outer margins with 1 tooth (Fig. $6 b)$. Maxillae brownish, longer than wide, curved, anteriorly wide and scopulate (Fig. 6c). Labium brown, nearly vase-shaped, posterior margin flat, medially wide, anterior margin little concave and scopulate (Fig. 6c). Sternum brown, longer than wide, anteriorly wider, posteriorly narrowed and pointed (Fig. 6d). Legs long and slender, clothed with strong black spines; leg formula and measurements (in $\mathrm{mm}$ ) : 4132 .

Table 5. Measurements ( $\mathrm{mm})$ of leg segments of Oxyopes sitae Tikader

\begin{tabular}{ccccccc}
\hline Leg & Femur & Patella & Tibia & Metatarsus & Tarsus & Total \\
\hline I & $4.10 / 4.10$ & $1.00 / 1.00$ & $2.90 / 2.90$ & $2.80 / 2.80$ & $1.10 / 1.10$ & $11.90 / 11.90$ \\
II & $3.00 / 3.00$ & $0.80 / 0.80$ & $2.50 / 2.50$ & $2.40 / 2.30$ & $0.90 / 0.90$ & $9.50 / 9.40$ \\
III & $4.00 / 4.00$ & $1.00 / 1.00$ & $2.50 / 2.50$ & $2.00 / 2.00$ & $1.00 / 1.00$ & $10.50 / 10.50$ \\
IV & $4.30 / 4.30$ & $1.20 / 1.20$ & $3.00 / 3.00$ & $3.00 / 3.00$ & $2.00 / 2.00$ & $13.50 / 13.50$ \\
\hline
\end{tabular}

Abdomen : long, cylindrical, anteriorly wide and posteriorly narrowed; dorsum clothed with lineraly arranged yellowish hairs and medially with-shaped brownish band; ventrally pale yellow with a grayish median longitudinal line; epigyne as in fig. $5 \mathrm{e}$.

Distribution : BANGLADESH ; Faridpur, Jhenidah, Khulna ; INDIA (Tikader 1970). 


\section{Oxyopes sunandae Tikader}

(Figure 7, a - e)

1970. Oxyopes sunandae Tikader, Rec. zool. Surv. India, 64(1-4) : 74.

2015. Oxyopes sunandae : Platnick, World Spider Catalog. Version 15.0 , http://research.amnh.org/iz/spiders/catalog/intro.html

Material examined : 1우, Bagerhat, 12.V.1991; 1우, Kustia, 18.X.1993; 1우, Mymensingh, 12.X.1991; 19, Sylhet, 20.XII.1993.

Genaral : Cephalothroax and legs brownish green; abdomen yellowish with dirty white dorsum. Total body length (female) $8.10 \mathrm{~mm}$. Carapace $3.65 \mathrm{~mm}$ long, $2.0 \mathrm{~mm}$ wide ; abdomen $4.45 \mathrm{~mm}$ long and $2.05 \mathrm{~mm}$ wide.

Cephalothorax : broad, longer than wide, posteriorly broad, anteriorly narrowed clothed with hairs and marginal pubescence; cephalic region little raised; thoracic region with a distinct fovea; radii distinct. Eyes yellowish, prominent, similar, each ringed with black basal band; anterior row recurved and posterior row procurved; ocelli present. Chelicerae brown, each of inner and outer margins with 1 tooth (Fig. 6b). Maxillae long, anteriorly little broad and scopulate (Fig. 6c). Labium basally wide, anteriorly narrowed and scopulate (Fig. 6c). Sternum nearly globoid, medially wide, anteriorly concave and posteriorly pointed (Fig. 6d). Legs long and strong, clothed with black, strong spines and sharp hairs; leg formula and the measurements (in $\mathrm{mm}$ ) : 4312.

Table 6. Measurements ( $\mathrm{mm}$ ) of leg segments of Oxyopes sunandae Tikader

\begin{tabular}{ccccccc}
\hline Leg & Femur & Patella & Tibia & Metatarsus & Tarsus & Total \\
\hline I & $4.00 / 4.00$ & $1.80 / 1.80$ & $2.40 / 2.40$ & $2.50 / 2.50$ & $1.50 / 1.50$ & $12.20 / 12.20$ \\
II & $3.50 / 3.50$ & $1.00 / 1.00$ & $2.00 / 2.00$ & $2.00 / 2.00$ & $1.00 / 1.00$ & $9.50 / 9.50$ \\
III & $4.00 / 4.00$ & $1.90 / 1.90$ & $2.50 / 2.50$ & $2.60 / 2.60$ & $1.30 / 1.30$ & $12.30 / 12.30$ \\
IV & $4.30 / 4.30$ & $2.00 / 2.00$ & $3.00 / 3.00$ & $3.00 / 3.00$ & $1.50 / 1.50$ & $13.80 / 13.80$ \\
\hline
\end{tabular}

Abdomen : longer than wide, anteromedially wide, posteriorly narrowed; clothed with fine hairs and pubescence; dorsum with a white longitudinal band; epigyne as in fig. 6e.

Distribution : BANGLADESH ; Bagerhat, Kustia, Mymensingh, Sylhet ; INDIA (Tikader 1970).

\section{DISCUSSION}

The paper deals with the taxonomic description of 6 (six) species of lynx spiders of which 4 species were new record for the study area. With regard to the distribution of the species, it may be stated that the maximum concentration of the same could be observed in the south-western part and minimum in the northern part of the area (Map-1). Among the species, O. javanus Thorell was maximum in number and $O$. sikkimensis Tikader was the minimum in the area. 
Comparing in the fields, the species richness in the crop-fields were in the day rather than gardens and other habitats. It was also observed that in fact, all the species are predatory in habit.

From the earlier records, it is found that among the present six species, four species are recorded for the first time from the area. All these species are slightly variable in colour, shape and external decoration from the species earlier described by different authors (Tikader 1969,1970 and Biswas et al. 1996) in the Indian Sub-continent.

Acknowledgements: The authors are grateful to Dr. S.C. Majumder, Scientist-SD, Zoological Survey of India, Kolkata for confirming the identity of the species and the Head, Department of Zoology, University of Calcutta for providing the laboratory facilities during the study.

\section{LITERATURE CITED}

BAO, Y. H. and YIN, C. M. 2002. A new species of the genus Oxyopes from China (Araneae: Oxyopidae). Acta Zootaxonomica Sinica, 27(4) : 720-721.

BARRION, A. T. and LITSINGER, J. A. 1995. Riceland spiders of South and South-east Asia. CABI-IRRI, 700p.

BISWAS, V., A. BEGUM, N. Q. KAMAL and KHAN, H. R. 1993. A preliminary report on the rice-field spiders of Jhenidah. Bangladesh j. Zool., 21(1) : 85-92.

BISWAS, V., B. KUNDU, M. KUNDU, S. SAHA and RAYCHAUDHURI, D. 1996. Spiders of the genus Oxyopes Latreille (Araneae : Oxyopidae) of Buxa Tiger Reserve, West Bengal. Acta Arachnol., 45 : 53-61.

BODKHE, A. K. and VANKHEDE, G. N. 2012. On two new species of spiders of the genus Oxyopes Latreille from central India (Arachnida : Araneae : Oxyopidae). Indian $J$. Arachnol., 1(1) : 150-155.

BRADY, A. R., 1964. The lynx spiders North America north of Mexico. Bull. Mus. Comp. Zool. Harv., 131(13) : 429-518.

BRADY, A. R., 1970. The lynx spiders Hamataliwa. Bull. Mus. Comp. Zool. Harv., 140(3) : 75-127.

CHOWDHURY, S. H. and NAGARI, S. 1981. Rice field spiders from Chittagong, Proc. Zool. Soc. Bangladesh : 53-72.

CHOWDHURY, S. H. and PAL, S. K. 1984. Further report on rice field spiders from Bangladesh. Chittagong Univ. Studies, II, 8(1) : 25-39.

DEELMAN, REINHOLD, C. L. 2009. Description of the lynx spiders of a canopy fogging project in north Borneo (Araneae : Oxyopidae), with description of a new genus and six new species of Hamataliwa. Zool. Mededelingen, Leiden, 83 : 673-700.

GAJBE, U. A., 1992. A new species Oxyopes latreille and one of Peucetia Thorell from Uttar Pradesh, India (Araneae : Oxyopidae). Rec. Zool. Surv. India, 91(3-4) : 389-393.

GAJBE, U. A., 1999. Studies on some spiders of the family Oxyopidae (Araneae : Arachnida) from India. Rec. Zool. Surv. India, 97(3) : 31-79.

GAJBE, U. A., 2008. Fauna of India and the adjacent countries : Spiders (Arachnida : Araneae : Oxyopide). Zoological Survey of India, Kolkata, pp : 117. 
MAJUMDER, S. C., 2007. Picterical Handbook on Spiders of Sundarbans, West Bengal. Zoological Survey of India, Kalkata, 138p.

MUKHTAR, M. K., 2013a. Two new species of the genus Oxyopes Latreille (Arachnida: Araneae : Oxyopidae) from Panjab, Pakistan. Pakistan J. Zool., 45 : 483-488.

MUKHTAR, M. K., 2013b. Description of two new species of the genus Oxyopes (Araneae: Oxyopidae) from Panjab, Pakistan. Pakistan J. Zool., 45(6) : 1511-1516.

MUSTAQ, S. and QADAR, A., 1999. Three new species of the genus Oxyopes (Araneae: Oxyopidae) from Pakistan. Pakistan J. Zool., 31 : 255-261.

OKUMA, C., N. Q. KAMAL, Y. HIRASHIMA, Z. ALAM and OGATA, T. 1993. Illustrated Monograph on the rice-field spiders of Bangladesh. IPSA-JAICA, 93p.

PATEL, B. H. 1978. A new species of spider of the family Oxyopidae from Gajrat, India, with notes on other species of the family. J. Bombay Nat. Hist. Soc., 74 : 327-330.

PLATNICK, N. I. 2014. World Spider Catalogue. Version 14.5. American Museum of Natural History. http://research.amnh.org/entomology

POCOCK, R. I., 1901. Description of some new species of spiders from British India. J. Bombay Nat. Hist. Soc., $13: 478-498$.

SAHA, S. and RAYCHAUDHURI, D. 2003. New lynx spider Oxyopes Latreille (Oxyopidae) from Buxa Tiger Reserve, Jalpaiguri, West Bengal, Entomon, 28 : 321-327.

SAHA, S. and RAYCHAUDHURI, D. 2004. A new species of spider of the genus Peucetia Thorell (Oxyopediae : Araneae) from Digha, Midnapore, West Bengal, India. J. Bombay Nat. Hist. Soc., 101 : 288-290.

SAHA, S. and RAYCHAUDHURI, D. 2007. Lynx spiders (Araneae : Oxyopidae) from Betla Forest, Jharkhand, India. J. Bombay Nat. Hist. Soc., 103 : 87-89.

SEN, S., S. SAHA and RAYCHAUDHURI, D. 2011. New species and new combination of Oxyopes Latreille 1804 (Araneae : Oxyopidae) females from India. World J. Zool., 6(4) : 339-345.

SHERRIFFS, W. R., 1951. Some oriental spiders of the genus Oxyopes. Proc. Zool. Soc., London, 120 : 651-677.

SONG, D. X., M. S. ZHU and CHEN, J. 1999. The Spiders of China. Hebei Sci. \& Tech. Pub. House, 640p.

TIKADER, B. K., 1965. On some new species of spiders of the family Oxyopidae from India. Proc. Indian Acad. Sci., 62 : 140-144.

TIKADER, B. K., 1969. Studies on some spiders of the family Oxyopidae from India. Oriental Insects, 3 : 33-36.

TIKADER, B. K. 1970. Spider fauna of Sikkim. Rec. Zool. Surv. India, 64 : 1-83.

TIKADER, B. K., 1987. Handbook Indian Spiders. Zoological Survey of India, Kolkata, 251p.

ZHANG, J. X., M. S. ZHU and SONG, D. X. 2005. Revision of the spiders genus Hamataliwa Keyserling from China (Araneae : Oxyopidae). Zootaxa, 1017 : 1-17.

(Manuscript received on 1 February, 2015; revised on 7 July, 2015) 


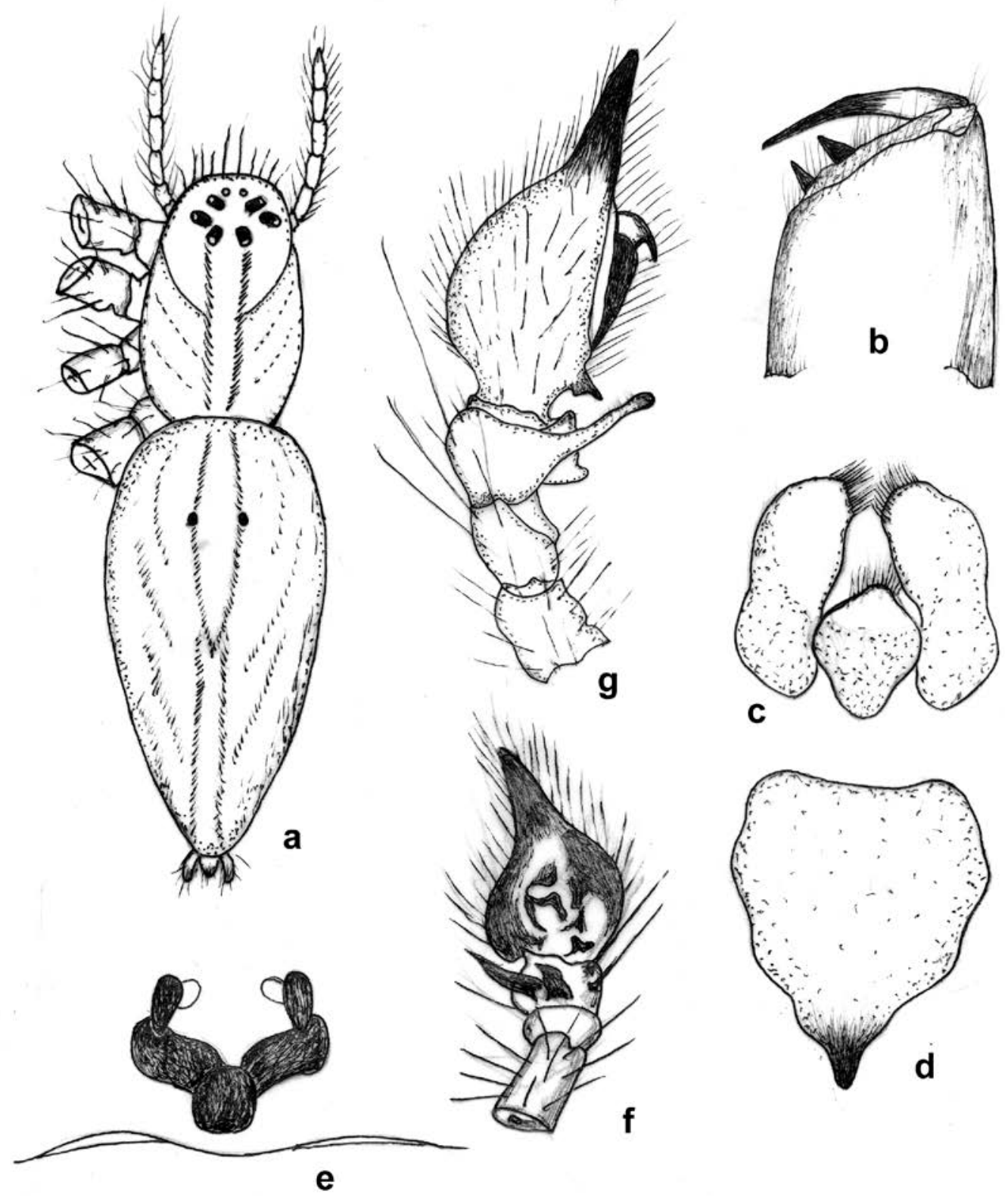

Fig. 2. Oxyopes pandae Thorell

a. Whole body (dorsal view) ; b. Chelicerae ;

c. Maxillae and Labium ; d. Sternum ; e. Male palp. 


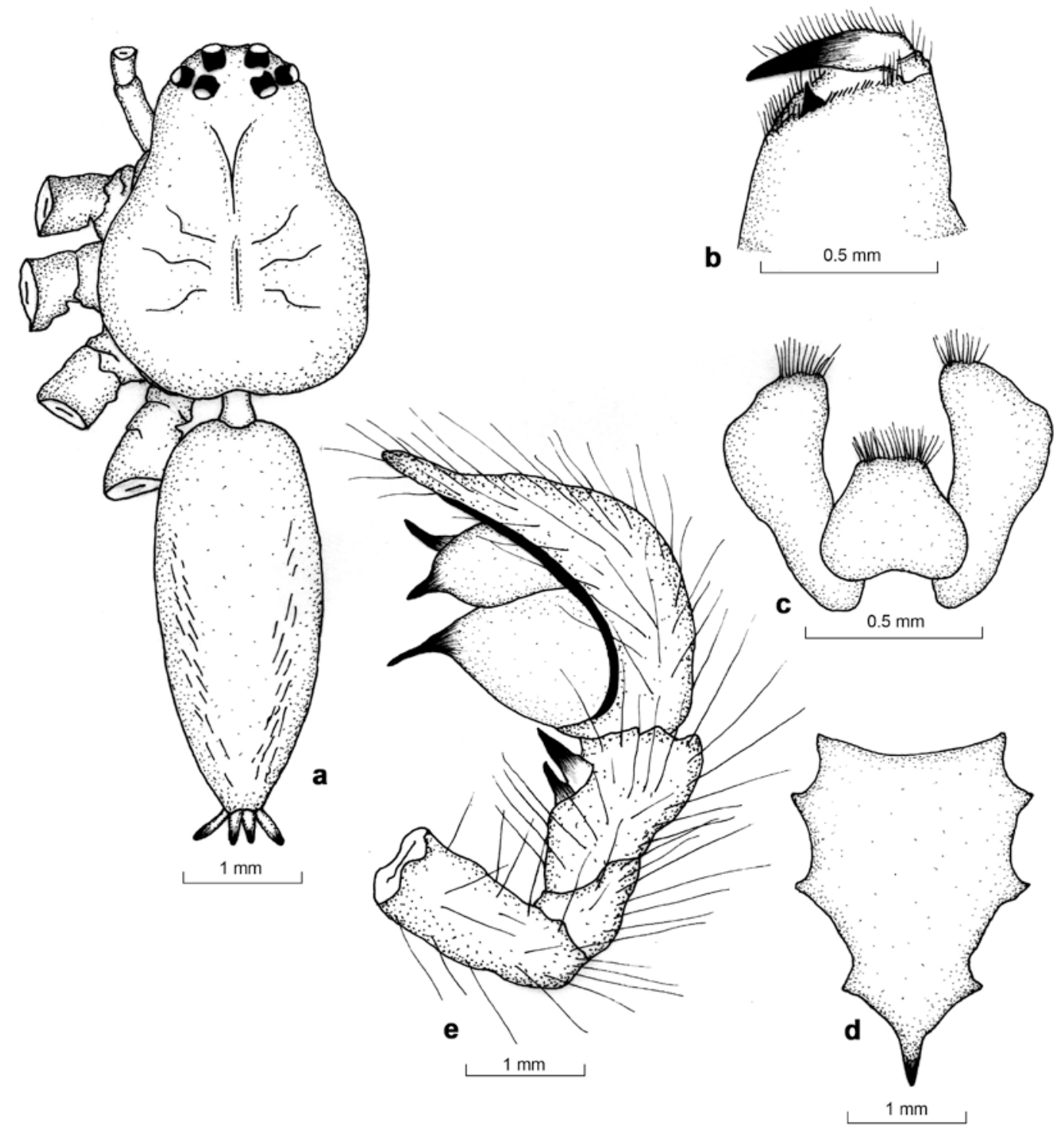

Fig. 3. Oxyopes pandae Tikader

a. Whole body (dorsal view) ; b. Chelicerae ;

c. Maxillae and Labium ; d. Sternum ; e. Male palp. 


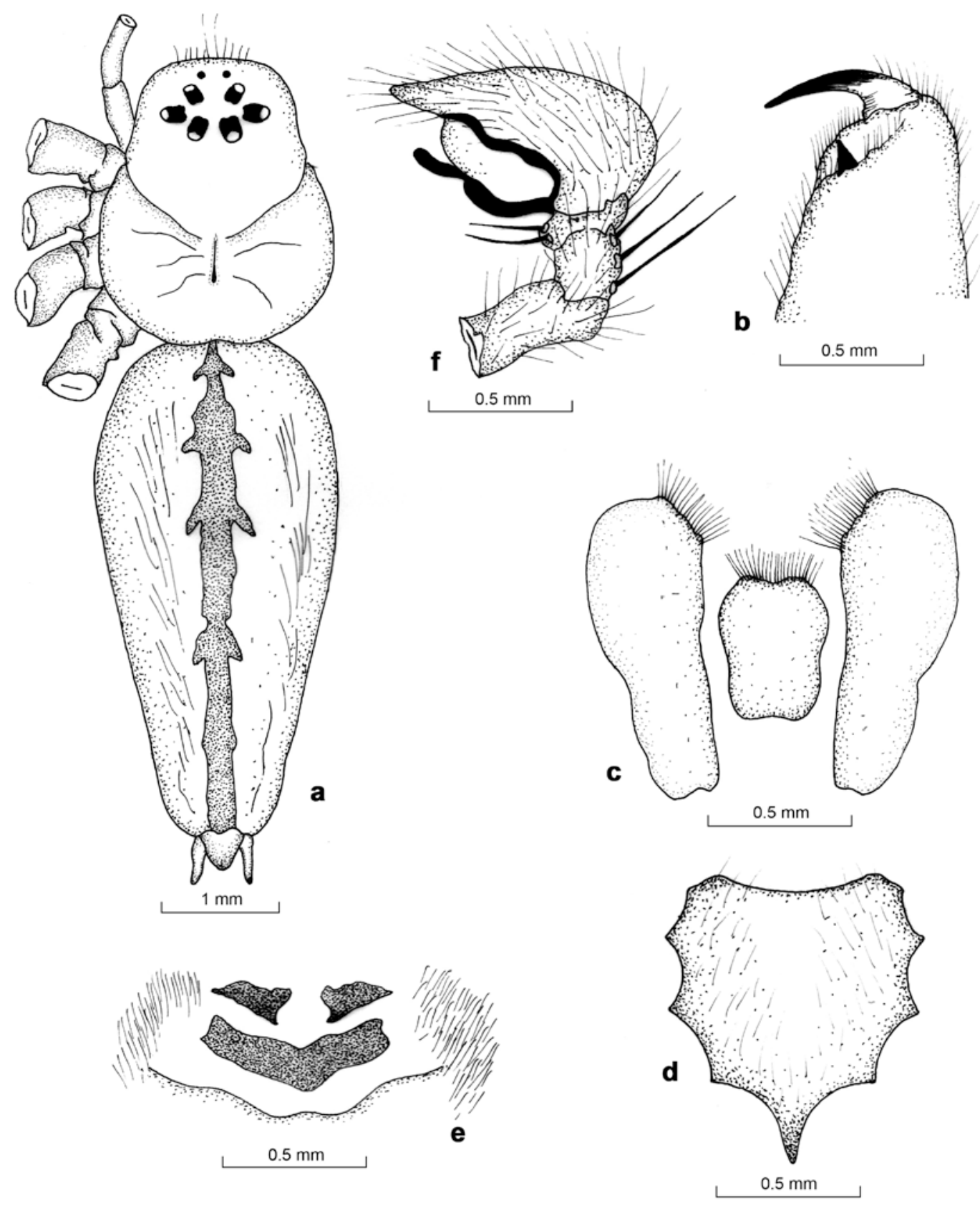

Fig. 4. Oxyopes ratnae Tikader

a. Whole body (dorsal view) ; b. Chelicerae ;

c. Maxillae and Labium ; d. Sternum ; e. Epigynum ; f. Male palp. 


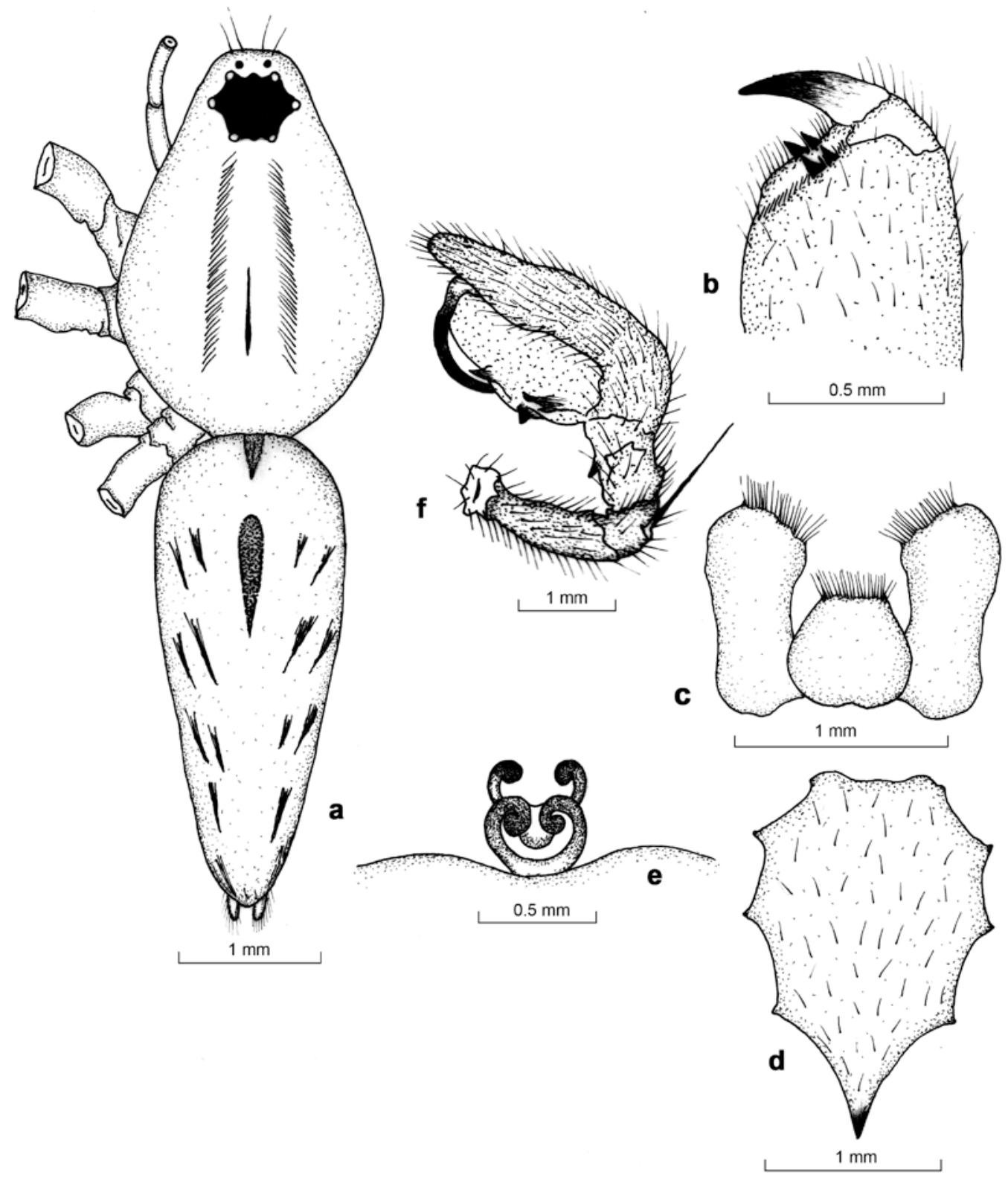

Fig. 5. Oxyopes sikkimensis Tikader

a. Whole body (dorsal view) ; b. Chelicerae ;

c. Maxillae and Labium ; d. Sternum ; e. Epigynum ; f. Male palp. 

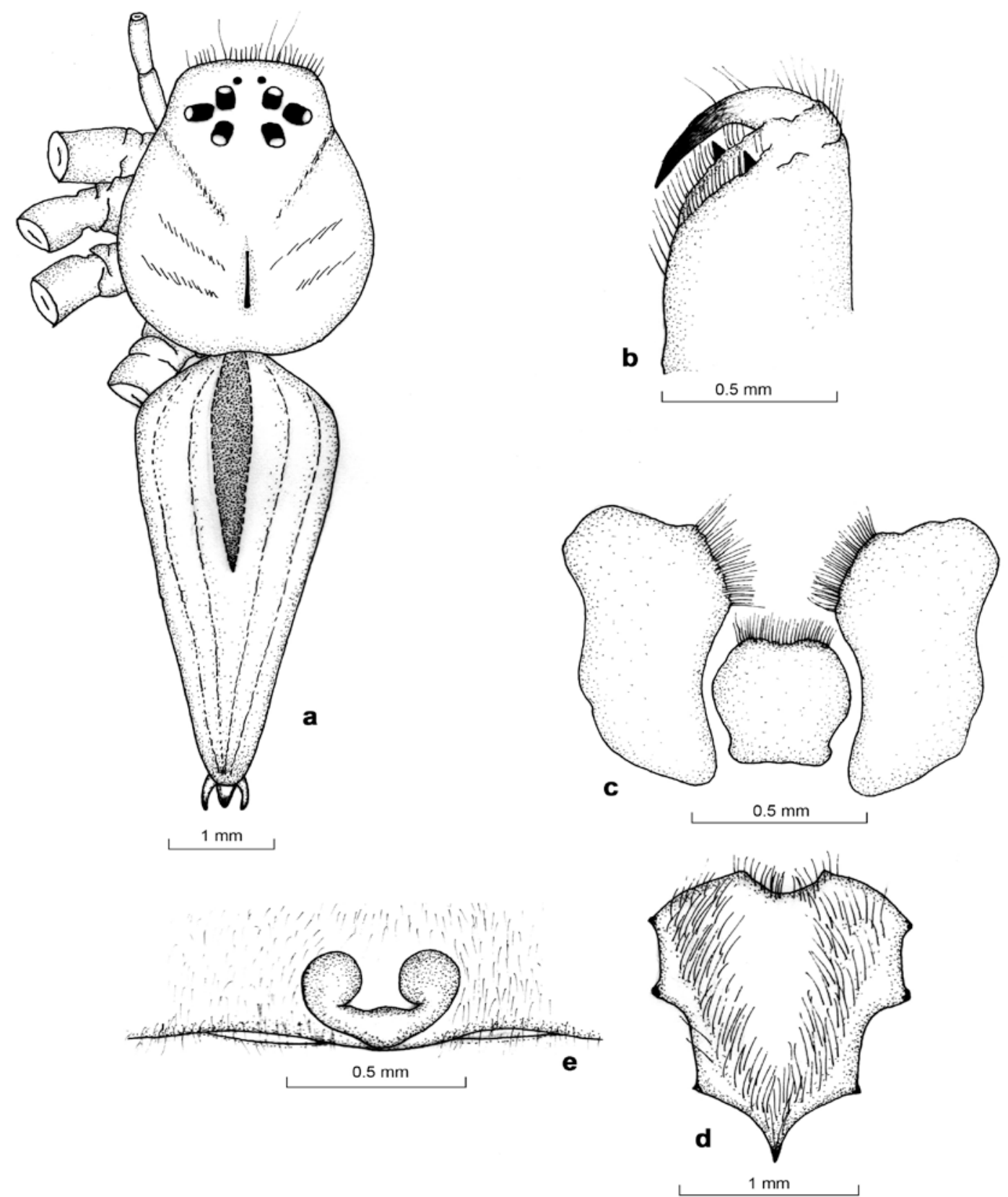

Fig. 6. Oxyopes sitae Tikader

a. Whole body (dorsal view) ; b. Chelicerae ;

c. Maxillae and Labium ; d. Sternum ; e. Epigynum. 

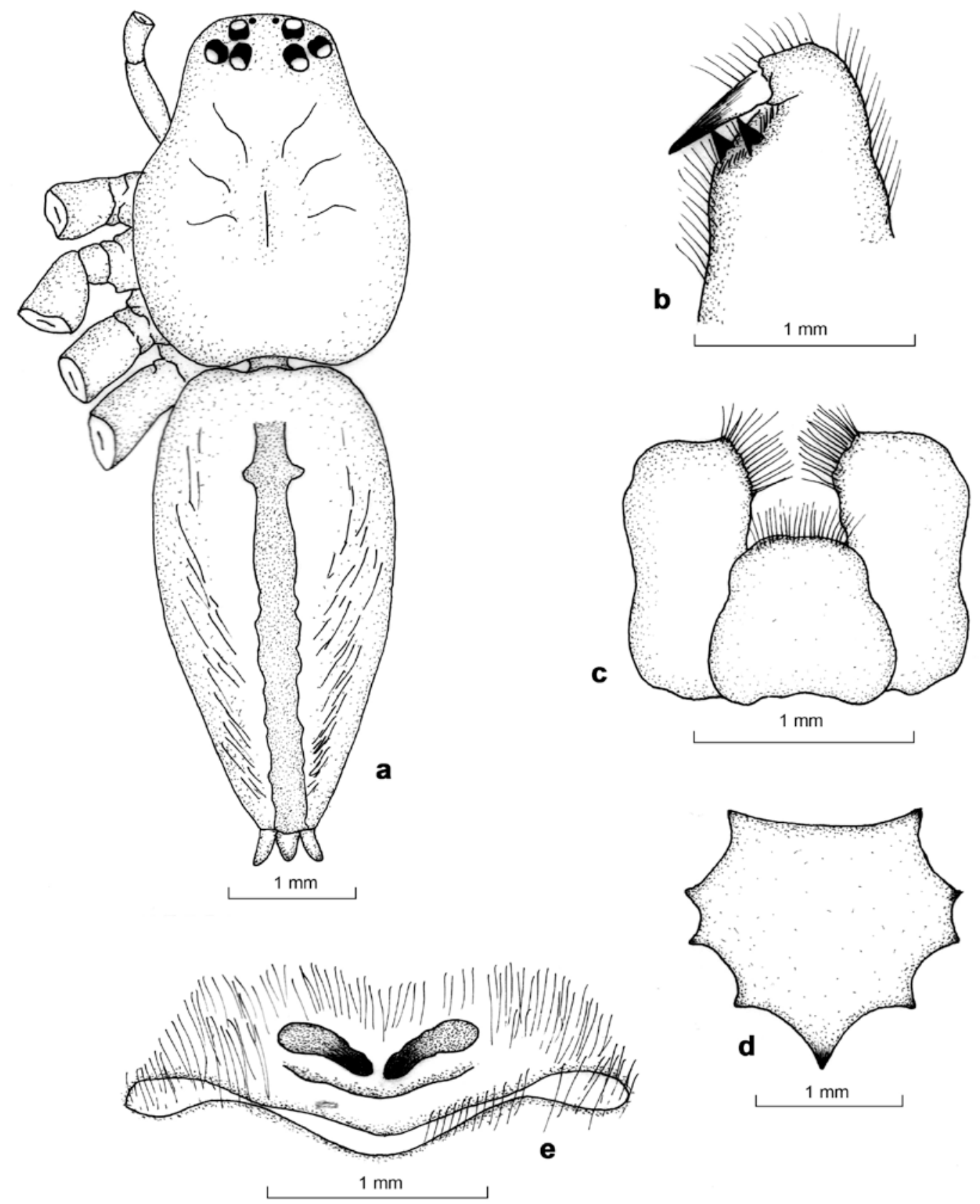

Fig. 7. Oxyopes sunandae Tikader

a. Whole body (dorsal view) ; b. Chelicerae ;

c. Maxillae and Labium ; d. Sternum ; e. Epigynum. 